\title{
CONSIDERING CONVERGENCE: A POLICY DIALOGUE ABOUT BEHAVIORAL GENETICS, NEUROSCIENCE, AND LAW
}

\author{
BRENT GARLAND* AND MARK S. FRANKEL**
}

\section{INTRODUCTION}

As the poet Mark Strand said, "The future is always beginning now." When considering the social impact that neuroscience and behavioral genetics will have on the criminal justice system, scientists, lawyers, courts, and policymakers might do well to keep Strand's words in mind. Too often it is assumed that for developments in science and technology, there is time to start the policy dialogue in "the future." Those who would address the issues later typically assert that the science in question is too immature, that it is too early, that the discussion is too speculative. While such objections sometimes have merit, it seems society is most often too slow in promoting a public dialogue.

Open public dialogue is an important tool in considering and weighing public reaction, in informing the public and policymakers, and in building public consensus about appropriate and responsible uses of science and technology. Scientific advancements can result in strong, negative public reactions, as with nuclear power in the United States, genetically modified food crops in the European Union, and human research cloning in a variety of nations. This negative backlash can in turn influence scientists and science policy and slow the progress of socially valuable research. When the social risks are great, it may be prudent to slow the pace of research. However, when the risks are

Copyright @ 2006 by Brent Garland and Mark S. Frankel

This Article is also available at http://law.duke.edu/journals/lcp.

* Brent Garland, M.S., J.D., Senior Program Associate with the Scientific Freedom, Responsibility and Law Program of the American Association for the Advancement of Science (AAAS). He recently edited the volume NEUROSCIENCE AND THE LAw: BRAIN, MIND AND THE SCALES OF JUSTICE (Brent Garland ed., 2004).

** Mark S. Frankel, Ph.D., Director of the Scientific Freedom, Responsibility and Law Program of AAAS. He was a lead investigator in a joint project between the AAAS and the Hastings Center on behavioral genetics and directed the AAAS project on neuroscience and the law.

The authors of this essay are neither neuroscientists nor geneticists. Rather, both are policy professionals whose work focuses on the ethical, legal, and social issues associated with the conduct of research and with advances in science and technology.

1. Mark Strand, The Babies, in ReAsons For Moving, Darker \& ThE SARgentville NOTEBOOK 19, 20 (1992). 
minimal, and the negative reaction is based on incomplete or inaccurate information about the science, then restraints on research serve little purpose.

Now is the time to call on scientists, lawyers, courts, and lawmakers to begin a sustained dialogue focused on the impact that scientific discoveries and technological advances might have on the criminal law. The dialogue should focus on developing appropriate policies to address the legal and social issues raised by such advances. Such a dialogue is necessary, in particular, concerning the focus of this essay: the impact of neuroscience and behavioral genetics on criminal law.

This article first briefly considers some of the commonalities and differences between behavioral genetics and neuroscience as they relate to the criminal law, including topics addressed by both fields, as well as how each field might be applied in criminal proceedings. The article then focuses on a common concern raised by both fields in this context-the possible misuse of science in the criminal law. It concludes with a proposal to address the need for a continuing policy dialogue about the law and scientific developments in neuroscience and behavioral genetics.

\section{II}

\section{A POLICY PERSPECTIVE}

The American Association for the Advancement of Science (AAAS) ${ }^{2}$ has sought to advance the public and policy dialogues in both behavioral genetics and neuroscience in the past few years. ${ }^{3}$ It is reasonable to ask why anyone would consider the effect on the criminal law of two broad scientific fields, rather than deal with each separately. It seems increasingly clear, though, that when describing, predicting, and understanding human behavior, numerous scientific discussions may be considered part of one larger discussion; various scientific fields converge in their exploration and explanation of human actions. It makes some scientific sense to talk about neuroscience and behavioral genetics together; indeed, the disciplines overlap and interact-for example, a person's genes affect how his brain develops. ${ }^{4}$ It similarly makes legal sense to

2. AAAS is a non-profit, non-governmental organization located in Washington, D.C. It is the largest general scientific organization in the world and publisher of the journal SCIENCE. According to its website, "AAAS serves some 262 affiliated societies and academies of science, serving 10 million individuals." About AAAS, http://www.aaas.org/aboutaaas. AAAS is "open to all and fulfills its mission to 'advance science and serve society' through initiatives in science policy; international programs; science education; and more." Id.

3. For more information, please see the website for the Scientific Freedom, Responsibility \& Law Program, http://www.aaas.org/spp/sfrl/about/mission.shtml. Of particular relevance are the Behavioral Genetics Project site, http://www.aaas.org/spp/bgenes, and the Neuroscience and the Law site, http://www.aaas.org/spp/sfrl/projects/neuroscience. Project publications are available for free download at both sites.

4. Another example of this overlap can be found in the emergence of a new, complex behavioral biology - one that will ultimately be not only descriptive but predictive. See Owen D. Jones \& Timothy H. Goldsmith, Law and Behavioral Biology, 105 ColuM. L. REV. 405 (2005). Many scientific disciplines will contribute to the knowledge base that will underlie such a biology. 
consider a larger behavioral biology, and it makes sense to consider the two fields together from a policy perspective. Moreover, public dialogues at AAAS and elsewhere on behavioral genetics and neuroscience suggest that both disciplines are ripe for further discussion about their nexus with criminal law and policy.

III

\section{COMMON ISSUES OF INTEREST}

Behavioral genetics and neuroscience converge on a number of scientific, legal, social, and ethical issues -in particular, on two areas of interest to the criminal justice system: the prediction of behavior and the use of behavioral information in the preliminary stages of criminal processes.

\section{A. Prediction of Behavior: Mitigation}

Both neuroscience and behavioral genetics have focused considerably on explaining and predicting behavior. ${ }^{5}$ Much discussion has focused on "ultimate" issues such as free will, determinism (genetic or mechanistic), and their effect on whether the concept of criminal culpability will be undone by new scientific discoveries. This seems unlikely, at least in the near future. ${ }^{6}$ A more intriguing and immediate concern is how scientific findings will affect the criminal law regarding the mitigation of criminal responsibility. For example, neuroscience and behavioral genetics seem particularly likely to play a role in addressing drug addiction; findings in both fields may be relevant to how society chooses to

5. Courts and prosecutors currently use prediction constantly—in plea bargaining, sentencing, decisions about levels of probation, and case diversion, among other proceedings. As the parties involved seek to weigh future risks, including the likelihood of recidivism, they do so knowing that our predictive models and abilities are really very poor. To the extent that neuroscience and behavioral genetics can better inform such predictions, the courts and criminal justice system could stand to benefit significantly.

The risk, of course, is that predictive decisions will be based on poor or incomplete science. Additionally, neuroscience-based or genetics-based predictions may be given undue weight as "scientific predictions" while still prone to the problems inherent in current risk prediction models, including construction bias in the normative or sample groups and the inability of predictive measures to provide information about any specific individual beyond probabilistic information about a group to which the subject belongs.

The pressing need for courts to make decisions about sentencing and risk management increases the risk for early adoption of immature "predictive models." The courts are in a difficult place with prediction - they cannot wait for the next round of peer-reviewed research results. See generally Erica Beecher-Monas \& Edgar Garcia-Rill, Danger at the Edge of Chaos: Predicting Violent Behavior in a Post-Daubert World, 24 CARDOZO L. REV. 1845 (2003) (discussing this challenge, particularly that juries should get both predictive information as well as details as to the limitations of such information).

6. Nor, indeed, will it be undone in the long term. As Stephen Morse has argued in the context of neuroscience, the idea of criminal responsibility is not an artifact of science, but, like law itself, a human construct that is mind-dependent; since we are constrained by our view of ourselves as rational agents, our constructs will reflect these views. This is admittedly a gross simplification of Morse's argument. See Steven J. Morse, New Neuroscience, Old Problems, in Neuroscience and the Law: Brain, MiND AND THE SCALES OF JUSTICE 157 (Brent Garland ed., 2004). 
handle criminal behavior that accompanies addiction, such as drug possession.' Neuroscience has shown that the brains of addicts are different from those of non-addicts, ${ }^{8}$ and there appears to be a genetic predisposition towards addiction. ${ }^{\prime}$ As with criminal behavior generally, the question arises whether such information (neuroscientific or genetic) should mitigate criminal responsibility, at least when there is evidence of neurological or genetic differences in the accused.

Neuroscience adds a gloss to this question by providing highly effective pharmaceutical treatments for opiate addiction that are currently available and yet not widely in use. ${ }^{10}$ One drug, naltrexone, serves to block the pleasurable or rewarding effect of the opiates by blocking the receptors to which the opiates bind, preventing their euphoric effects. ${ }^{11}$ As long as the individual is compliant in taking naltrexone, relapse, in the sense of experiencing the pleasurable aspects of opiate use, is impossible. Successful drug treatment not only reduces the health risks associated with drug use, but also eliminates the legal risk of incarceration for possession of drugs or drug paraphernalia. Drug addicts could, in theory, be diverted to a mandatory treatment program at a much lower cost than incarceration. Thus, by changing the way that society views and understands addiction, drug use, and treatment, neuroscience has the potential to reshape our policies on criminalization and incarceration as they pertain to drug-related offenses.

Indeed, mitigation is the most obvious issue that the scientific, legal, and policy communities must face with some immediacy. This need was highlighted most recently by the Supreme Court decision in Roper v. Simmons, which barred capital punishment for juvenile offenders under the age of eighteen. ${ }^{12}$ The opinion referred to "the scientific and sociological studies" 13 cited by the respondent and amici as confirming a "lack of maturity and an underdeveloped sense of responsibility" found in the young. ${ }^{14}$ Several amici briefs ${ }^{15}$ cite brain

7. The potential upside for better understanding addiction is important since treating addiction is viewed by many as a long-term, if not lifelong, process. The relapse rate is high, and the legal penalties for illegal drug use are substantial.

8. See, e.g., Alan I. Leshner, Addiction is a Brain Disease, and It Matters, 278 SCIENCE 45 (1997); Nora D. Volkow, Beyond the Brain: The Medical Consequences of Abuse and Addiction, NIDA NOTES, Feb. 2004, at 3. (2000).

9. For a brief review article, see Eric J. Nestler, Genes and Addiction, 26 NATURE GENETICS 277

10. Neuroscience can offer a brain-based treatment in a way that behavioral genetics cannot-that is, behavioral genetics is unlikely to offer a form of gene therapy for addiction anytime soon. See, for example, Charles P. O'Brien, A Range of Research-Based Pharmacotherapies for Addiction, 278 SCIENCE 66 (1997).

11. For a brief overview of these treatments, see Christian A. Heidbreder \& Jim J. Hagan, Novel Pharmacotherapeutic Approaches for the Treatment of Drug Addiction and Craving, 5 CURRENT OPINION IN PHARMACOLOGY 107 (2005). Opiates are not the only drugs for which new treatments are being developed. For example, one vaccine, TA-CD, reduces the euphoric effects of cocaine. Cocaine Vaccine Trials Progress, BBC NEws, Apr. 2, 2002, http://news.bbc.co.uk/1/hi/health/1906823.stm.

12. 125 S. Ct. 1183 (2005).

13. Id. at 1195 .

14. Id. (quoting Johnson v. Texas, 509 U.S. 350, 367 (1993)). 
studies as offering evidence of immaturity and lack of judgment sufficient to mitigate a juvenile's culpability, even when the juvenile engages in the worst behavior-behavior for which society reserves the death penalty. ${ }^{16}$

In comparison, the well-known Brunner study of a Dutch family in the $1990 \mathrm{~s}^{17}$ helped raise a similar question regarding whether behavioral genetics should be considered in mitigation. The study discovered a very rare defect in the gene encoding for monoamine oxidase A (MAOA), an enzyme that helps break down certain neurotransmitters. ${ }^{18}$ The defect appeared to correlate with antisocial behavior, ${ }^{19}$ which raised the obvious question of how such a finding might be used in arguing for mitigation in criminal cases.

Shortly after the research was published, defense counsel in a death penalty case filed a motion seeking funds to determine whether their client suffered from a deficiency of enzymatic activity for MAOA, with a request for follow-up genetic testing as well. ${ }^{20}$ The trial court denied the defense request, "finding that the theory behind the request for funds will not have reached a scientific stage of verifiable certainty in the near future and that [the defendant] could not show that such a stage will ever be reached." ${ }^{21}$

Although the court was correct in rejecting the science as premature, research continues on the correlation between MAOA and antisocial behavior. Subsequent research published in 2002 suggests that children with low MAOA expression who are maltreated may be at a greater risk for antisocial behavior, ${ }^{22}$ though a more recent study failed to replicate those findings. ${ }^{23}$ Similar MAOA challenges are likely in the future as the literature evolves.

Even if MAOA challenges or other arguments based on behavioral genetics are accepted by courts in the future, it is not always clear which way scientific

15. See Juvenile Death Penalty Amicus Briefs, http://www.abanet.org/crimjust/juvjus/simmons/ simmonsamicus.html (last visited May 24, 2005).

16. Although the Court did not directly cite any specific amicus brief, several amici supporting the respondent cited neuroscientific support for their position. Although none could conclude that the neuroscience was controlling in the Court's decision in Roper, it is reasonable to expect that lawyers will be citing to neuroscience developments in the future. For example, the amicus brief filed by the American Psychological Association and the Missouri Psychological Association argued that neuropsychological research suggests that the adolescent brain is not as developed as the mature adult's brain; similarly, the brief filed by the American Medical Association made a similar "immature brain" argument. See id.

17. H.G. Brunner et al., Abnormal Behavior Associated With a Point Mutation in the Structural Gene for Monoamine Oxidase A, 262 SCIENCE 578 (1993).

18. Id. at 579 .

19. Id.

20. Mobley v. State, 455 S.E.2d 61, 65 (Ga. 1995). See also Deborah W. Denno, Legal Implications of Genetics and Crime Research, in GENETICS OF CRIMINAL AND ANTISOCIAL BEHAVIOR 248, 251-53 (Gregory R. Bock \& Jamie A. Goode eds., 1996).

21. Mobley, 455 S.E.2d at 66.

22. Avshalom Caspi et al., Role of Genotype in the Cycle of Violence in Maltreated Children, 297 SCIENCE 851 (2002).

23. Brett C. Haberstick et al., Monoamine Oxidase A (MAOA) and Antisocial Behaviors in the Presence of Childhood and Adolescent Maltreatment, 135 AM. J. MED. GENETICS (PART B: NEUROPSYCHIATRIC GENETICS) 59 (2005). 
knowledge will cut when introduced at trial. For example, while a defendant could argue for mitigation due to some genetic propensity or neurological defect ("bad genes" or a "bad brain" led him astray), the prosecution could make a counterargument for aggravation, saying that the defendant is even more dangerous because he is biologically predisposed to commit crime and thus should be incarcerated rather than given probation. This mirror side to mitigation arguments should also be included in the policy dialogue.

\section{B. Preformal Uses}

Neuroscience and behavioral genetics converge on issues other than mitigation related to how and when to use possibly relevant findings from these sciences:

[A significant fear], both in the behavioral genetics area and with [neuroscience], is that there are no [rules of evidence] that control the use of these kinds of technologies in the preformal stages of criminal processes. When it gets to the formality of sentencing, the cry will come up, but the ability of judges and prosecutors to make decisions about whether they're going to initiate charges, [whether] they're going to accept diversion [from criminal prosecution] for people, et cetera-using [neuroscience tests] that haven't been validated-is a serious risk that the technology poses. $^{24}$

Such concerns offer a good example of a policy question that also needs to be addressed in the near future: how neuroscience and behavioral genetics findings might be used by the legal system in "preformal" settings-that is, prior to bringing criminal charges. For example, defense counsel could bring test results to prosecutors as part of a precharging dialogue, seeking dismissal, reduction of charges, or some other outcome. ${ }^{25}$ Such usages would essentially be unreviewable and possibly nonpublic. In addition, such information could be considered without even the minimal protections offered by the Daubert ${ }^{26}$ or Frye $^{27}$ tests regarding admissibility in formal proceedings. ${ }^{28}$ Although the exact

24. NeUROSCIENCE AND THE LAW, supra note 6, at 38 (quoting neuroscientist participant).

25. To give the prosecution their fair share of concern, district attorneys could seek genetic or neuroscientific information in deciding to bring charges, or use it in arguments to a grand jury to secure an indictment.

26. See Daubert v. Merrell Dow Pharmaceuticals, Inc., 509 U.S. 579 (1993), superseded by statute, FED. R. EVID. 702.

27. See Frye v. United States, 293 F. 1013 (D.C. Cir. 1923).

28. The admissibility of scientific information into evidence at trial is generally governed by two approaches:

(1) The Frye standard allows for the admission of scientific evidence when the scientific technique, data, or method is generally accepted by the scientific community in the relevant field. $293 \mathrm{~F}$. at 1014. The courts relied on the members of the relevant scientific discipline for the standard, with "general acceptance" usually being proven through additional expert testimony, the citing of standard reference materials in the discipline, and various other methods. Id.

(2) The newer approach, and the one now codified in the Federal Rules of Evidence, is the Daubert standard, which offers four criteria for courts to use in their evaluations: (a) falsifiability, which asks if the theory or technique can be (and has been) tested; (b) subjection of the theory or technique to peer review; (c) the known or potential error rate of the methodology or technique; and (d) a Frye-like general acceptance criteria. 509 U.S. at 592-95. The four elements form a flexible rule, one whose 
nature of these preformal usages is unclear, it seems prudent for policymakers, lawyers, and scientists to consider how such uses might be addressed in ways that are socially, legally, and scientifically appropriate.

\section{IV}

\section{INSTRUCTIVE DIFFERENCES}

Both genetics and neuroscience raise many of the same policy questions when it comes to issues such as the prediction of behavior, but there are obviously areas in which the fields differ. Nevertheless, even when there are differences, the policy dialogue can be enriched by considering the two fields together. The dialogue that has already begun about genetics may serve to inform and shape the way society thinks about neuroscience, and neuroscience may have some lessons for behavioral genetics as well. For example, genetics in general garnered a fair amount of early attention from the public and policymakers. As the human genome project advanced, lawmakers in several states enacted laws to protect genetic information and to guard against potentially discriminatory uses. ${ }^{29}$ This was an unusual and entirely proactive approach to policymaking, as there had generally been no litigation about genetic discrimination at that point. The mere specter of risk of misuse of genetic information had caused lawmakers to act.

Yet no such actions have been spurred on by recent developments in neuroscience. The link between brain and behavior is much closer than the link between genes and behavior, but the attention to genetics research and its broad social implications has far outweighed that given to neuroscience and technology. ${ }^{30} \quad$ Neuroscience could likely benefit from the same public consideration and policy dialogue.

\section{A. Essentialism and Exceptionalism}

The potential impact of genetic "exceptionalism" "essentialism" ${ }^{32}$ is an area in which the policy dialogue in genetics has outpaced

focus should be on determining scientific validity, meaning the evidentiary relevance and reliability. Id. at 594-95.

29. E.g., NEV. REV. STAT. $§ 613.345$ (2005) (forbidding the use of genetic testing for employment). Although the U.S. Congress has yet to pass comprehensive legislation to prevent genetic discrimination, bills have been proposed several times. For example, in 2003, the Senate passed the Genetic Information Nondiscrimination Act, but the bill failed to pass the House. S. 1053, 108th Cong. (2004). The Senate has passed the bill again in the current Congress. Genetic Information Nondiscrimination Act, S. 306, 109th Cong. (2005). See also Sonia M. Suter, The Allure and Peril of Genetics Exceptionalism: Do We Need Special Genetics Legislation?, 79 WASH. U. L.Q. 669 (2001) (providing a brief overview and analysis of some state genetic information laws).

30. See Open Your Mind, THE ECONOMIST, May 23, 2002, at 79 (discussing the legal implications of neuroscientific research).

31. In genetics, a concern has arisen that passing laws and special rules for genetic discrimination (rather than treating such matters under current anti-discrimination schemes, like the Americans with Disabilities Act, 42 U.S.C. $\$ \S 12101-12213$ (2000)), will result in a perception by the public that genetic factors are more important and determinative of our well-being and behavior than they actually are. This singling out of genetic information for special protection seems to indicate an exceptionally 
the dialogue in neuroscience and in which the thinking on genetics has been especially instructive. Both exceptionalism and essentialism deal with the idea that the public may perceive scientific information about a person as being more powerfully determinative than it in fact is.

For genetics, these constructs seem to have worked well in guiding discussion and in thinking about appropriate policy. However, the essentialism argument may not be as obvious in neuroscience as it is in genetic science. ${ }^{33}$ People may see their brains as being much more "who they are" than their genes, and they may accordingly offer less resistance to using neuroscientific information in criminal and other court proceedings. This aspect of brain science may not have even been considered as potentially problematic, had it not been for the genetics policy debates.

\section{B. Truth-telling}

Neuroscience may have something instructive to offer behavioral genetics in the field of truth-telling, ${ }^{34}$ since it is more likely than behavioral genetics to develop techniques to tell when someone is lying. The development of accurate and reliable neuroscience-based lie detection is already being vigorously explored by researchers, and this has obvious value to the law. ${ }^{35}$ If such

powerful amount or type of knowledge-hence, genetic exceptionalism. A similar concern would arise regarding neuroscientific information.

32. Essentialism is the idea that the person is reducible to some limited element of their biology, that is, "I am my genes" or "I am my brain."

33. As Stanford law professor Henry Greely observed in the AAAS neuroscience and law meeting, "It seems to be quite possible that I am my mind or I am my brain in a way that I'm quite clear I am not my genes. My genes are not me. My mind, my brain, well, maybe that is me." NEUROSCIENCE AND THE LAW, supra note 6, at 34 (quoting Greely).

34. Lie detection tests have frequently been held to be inadmissible, in part due to concerns about the accuracy and reliability of techniques such as the polygraph. E.g., United States v. Scheffer, 523 U.S. 303, 309-12 (1998). For the types of questions discussed in the body of this paper, it is assumed that neuroscience is likely to eventually produce substantially more accurate and reliable testing in order for it to be admissible and relevant.

For a more in-depth discussion of some legal implications of neuroscience-based lie detection, see Henry T. Greely, Prediction, Litigation, Privacy, and Property: Some Possible Legal and Social Implications of Advances in Neuroscience, in NEUROSCIENCE AND THE LAW, supra note 6, at 114. Greely notes several bases for excluding lie detection tests from court proceedings, including accuracy concerns and invasion of the purview of the jury in their role as finder of fact. Id. See also Laurence R. Tancredi, Neuroscience Developments and the Law, in NEUROSCIENCE AND THE LAW, supra note 6, at 71.

35. This is an area of strong research interest and is becoming increasingly sophisticated. For example, one of the most significant hurdles facing accurate lie detection is what could be termed "the problem of unintentional deceit." Although techniques might be developed to detect when someone is intentionally lying, there might be real difficulty in detecting when someone is merely mistaken-that is, when they are engaging in unintentional deceit, subjectively telling the truth but being factually in the wrong. See Paul Root Wolpe, et al., Emerging Neurotechnologies for Lie Detection: Promises and Perils, 5(2) AM. J. BIOETHICs 1 (2005) (detailing some of the overall problems associated with lie detector technology). Yet, even this difficult problem seems to be gradually yielding to researchers. See Scott D. Slotnick \& Daniel L. Schacter, A Sensory Signature that Distinguishes True from False Memories, 7 NAture Neuroscience 664 (2004); Daniel L. Schacter \& Scott D. Slotnick, The Cognitive Neuroscience of Memory Distortion, 44 NEURON 149 (2004), available at http://www.wjh.harvard.edu/\%7Eslotnick/articles/slotnick04_nat_neurosci_supp.pdf. 
technology were to be successfully developed, lie detection could be used to evaluate the testimony of witnesses and defendants, to challenge jurors' responses in voir dire, or to poll the jury following a verdict. Courts would have to determine whether witnesses or defendants could be compelled to be tested for truthfulness and whether the judge or jury should be allowed to consider the refusal of a witness to take such a test. All of these would be just the tip of the iceberg.

Issues surrounding the acceptability and legality of compelled neurosciencebased testing, including court decisions regarding when and how to use lie detection technology, would likely be instructive for any behavioral genetics tests that develop (such as one to determine a propensity for impulsive violence for use in either mitigation or evaluations of future risk).

\section{$\mathrm{V}$ \\ A SHARED HISTORY}

Just as both fields share common areas of interest and application, they share a common problem - the problem of history. The history of the criminal law and science is one that makes people cautious. Prior uses of science to underpin law by politicians and policymakers include examples in which developing science was misused, and sometimes exploited, occasionally to brutal ends. ${ }^{36}$ Because of this history, any attempt to understand criminality from the basis of biology will suffer from suspicion and doubt, and many will have concerns that any such research findings or technologies will be used in oppressive and reactionary ways. These public concerns about the possible abuse of science push just as strongly for a broad policy dialogue as do the hopes for valuable uses. ${ }^{37}$ One might call this "the curse of Lombroso" haunting risk that immature science could be adopted and used for political and social purposes that feed into the worst of human behavior.

History provides several examples of misguided efforts to apply science to the study of criminality and to use such findings to make policy and law. By

36. See, e.g., NiCOlE HAHN RAFTER, CREATING BORN CRIMINALS (1997) (offering an overview of biological theories of criminality from the nineteenth and twentieth centuries); Paul A. Lombardo, Genes and Disability: Defining Health and the Goals of Medicine: Taking Eugenics Seriously: Three Generations of ??? Are Enough?, 30 FLA. ST. U.L. REV. 191 (2003) (considering contemporary genetic science in the context of the history of eugenics in America).

37. The potential for discriminatory or eugenic uses of modern genetics research is a good example of a modern public concern. See Garland E. Allen, Is a New Eugenics Afoot?, 294 SCIENCE 59 (2001) (providing a historical overview of the development of the eugenics movement). See also Paul A. Lombardo, Medicine, Eugenics, and the Supreme Court: From Coercive Sterilization to Reproductive Freedom, 13 J. CONTEMP. HEALTH L. \& POL'Y 1 (1996) (discussing how the eugenics laws continue to play a role in our modern legal thinking).

38. Cesare Lombroso was a nineteenth-century Italian physician who developed the idea that criminals could be detected scientifically through anthropomorphic measurements. Lombroso put forth the idea of the "born" criminal; while his theories were disproven, other concepts of the "born" criminal (or of innate criminality) would continue to play a dangerous role well into the twentieth century, including through the American eugenics movement. 
now the examples are familiar-from Lombroso's work in the 1800s to identify criminals by anthropomorphic measurements, to the hereditarian theories of some phrenologists, to the development of degeneration theory in the early twentieth century. ${ }^{39}$ Perhaps the most horrible American example of science being misused in policy and the law was the development of eugenic sterilization laws in the 1920s and 1930s-laws that sought to forcibly sterilize the "feeble-minded," spurred at least in part by the intent to eliminate "inherited criminality." Anyone with any interest in this topic remembers the chilling words of Justice Holmes in Buck v. Bell, "Three generations of imbeciles are enough." ${ }^{\prime 0}$ Perhaps the coldest chill, however, comes from the sentences preceding that famous line:

It is better for all the world, if instead of waiting to execute degenerate offspring for crime, or to let them starve for their imbecility, society can prevent those who are manifestly unfit from continuing their kind. The principle that sustains compulsory vaccination is broad enough to cover cutting the Fallopian tubes. ${ }^{41}$

The Supreme Court upheld the compulsory eugenic sterilization laws of Virginia, other states took them as a model, and many people were forcibly sterilized under these laws.

Although the history of American eugenics may be one of the most inflammatory examples of science being misused to make bad law and bad policy, not every time science and the criminal law meet means a disaster in the offing. The law is not always easily swayed by attempts to use bad or immature science. For example, during the 1960 s a theory emerged regarding males who possessed an additional Y-chromosome. ${ }^{42}$ These so-called "XYY males" were thought to be particularly aggressive and inclined to violence and criminality. ${ }^{43}$ In general, courts rejected attempts to admit such information. ${ }^{44}$ The impact on the law, such as it was, was rather mild, and eventually, the concept of the XYY male as someone who posed a high risk for criminal behavior was discredited. ${ }^{45}$

What the eugenics experiment and the XYY theory have in common is the extent to which developing science was seized upon and used by nonscientistspolicymakers, politicians, judges, and lawyers-who sought to dress their agendas in the trappings of legitimate scientific debate. In part, the ability to misuse science (and for lawyers to ineffectively combat such misuse) comes from the different approaches of the two cultures. Science has a narrowing, problem-focused method, and its discoveries are seen as part of a continuing dialogue, open to change in light of new information. The timeline is long, the knowledge slowly built up, but the entire system is open to complete

39. See generally RAFTER, supra note 36 , (detailing a history of these examples).

40. 274 U.S. 200, 207 (1927).

41. $I d$.

42. Deborah W. Denno, Comment, Human Biology and Criminal Responsibility: Free Will or Free Ride?, 137 U. PA. L. REV. 615, 619-20 (1988).

43. Id.

44. Id. at 620 .

45. See id. at 622 . 
upheaval-hypotheses, after all, prompt disproof as well as proof. Science values consensus and replicability.

Lawyers and judges, on the other hand, often operate with little knowledge of science and the scientific method and work on a more pressing timeline to solve the problems immediately before them. Law moves forward on advocacy - using the tools available at the time the conflict must be addressed.

Policymakers add a third approach to the mix-one driven by political concerns and marginally limited in what issues can be considered in formulating positions. Lawyers and scientists are somewhat constrained by the rules of law and peer review, respectively. Policymakers, on the other hand, have broad, wide-sweeping powers and can seize on and implement policies with farreaching impacts that, once in place, can be quite difficult to revise.

\section{VI \\ CONCLUSION}

The potential impact of neuroscience and behavioral genetics on the criminal law, the extent to which the fields converge on common areas, the history of science and the criminal law, and the potential for policymakers to seize on early findings for political goals all lead to this conclusion: The time for a deep, broad, science-driven policy discussion is now. Both neuroscience and behavioral genetics sit at the courtroom door. ${ }^{46}$ The issues at the forefront are not the more academic and philosophical ones of causation, free will, determinism, and responsibility, but rather those posed by technologies that are poised to come into courtroom and preformal use soon. These technologies will lay the legal foundations for how courts think about and utilize these developing sciences, possibly for years to come. ${ }^{47}$

46. In fact, neuroscience has already entered the courtroom for a visit. See Roper v. Simmons, 125 S. Ct. 1183 (2005) (forbidding the death penalty for juvenile offenders in light of their ongoing psychological and emotional development).

47. Oftentimes, the fear is that weak or immature science will be accepted into evidence by a court, to be followed by a flood of decisions influenced by bad science. There are other possible negative effects as well, including when the introduction of science seen as weak or immature results in a ban on all such evidence. For example, in Virginia, a line of cases bars any and all testimony regarding a defendant's mental state, unless an insanity defense is being asserted:

The state of knowledge in the fields of medicine and psychiatry is subject to constant advance and change. The classifications and gradations applied to mental illnesses, disorders, and defects are frequently revised. The courts cannot, and should not, become dependent upon these subtle and shifting gradations for the resolution of each specific case.

Stamper v. Commonwealth, 324 S.E.2d 682, 688 (Va. 1985) (citing Fisher v. United States, 328 U.S. 463 (1946), and Wahrlich v. Arizona, 479 F.2d 1137 (9th Cir. 1973)). The level of scientific proof and relevance needed to reverse the ruling in Stamper remains unclear. In the interim, the evidentiary bar would appear to preclude any and all testimony about mental state, be it psychiatric, psychological, medical, or neurological. This bar has precluded testimony regarding the mental capacity of a defendant in a malicious wounding case in which the defendant, who had an established history of mental retardation and an estimated IQ of 65, shook and injured his infant son. Funk v. Commonwealth, No. 1821-02-4, 2003 Va. App. LEXIS 383 (2003). See also Peeples v. Commonwealth, 519 S.E.2d 382, 386 (Va. Ct. App. 1999) (upholding the exclusion of expert testimony from psychologist in aggravated malicious wounding case, where defense sought to admit evidence to rebut assumption of 
Members of the scientific, legal, and criminal justice professions should join forces to advise and inform policymakers and the public on the scientific, legal, and social issues associated with advances in neuroscience and behavioral genetics. This effort should strive to engage policymakers to make better, more fully informed decisions about science, the criminal law, and policy-decisions that would hopefully reduce the risks of the following: unwarranted backlash to developments in science and technology, poorly informed legislation, and judicial decisions based on inappropriate or immature science. If this multidisciplinary effort were successful in establishing itself as a valued resource and authority, the models it develops for assisting in the policy process could be applied to other areas of science, technology, and law.

The proposal is not intended as a "thought experiment" or an academic exercise. Failure to try such an approach will leave these matters to the vagaries of the political process or to a court system that is unprepared to address complex issues of science. The very structure of the court system presses against the development of coherent and unified policies-courts develop policies as legal challenges are presented, not from a proactive, forward-looking approach. As a consequence, the results may impair scientists' ability to conduct research and society's ability to benefit from useful technology. Moreover, the adoption of controversial, poorly understood, and immature science by the courts or law enforcement could undermine public confidence in the legal system, as well as unfairly affect the rights of citizens.

The initial political challenge facing such an effort will be to convince policymakers in all branches of government that the analysis is timely and relevant to them in governing. To achieve this goal, the analysis must be capable of transcending narrow partisan and professional interests and should therefore reach out to a broad range of stakeholders in a genuine dialogue based on mutual respect for differences of opinion. Such a dialogue should help to confer legitimacy on various policy options. It is not enough that the dialogue be only among colleagues in a particular discipline, but it must also be conducted across fields, so that both the participants and the larger group of stakeholders may understand the wider context. Broad, integrative thinking about what the sciences reveal to us about how we behave will help to shape better policy-from statutes and regulations to courtrooms.

The ultimate challenge, however, is how to have a substantial and longlasting effect on policymaking. The proposed effort must connect to government but cannot be captured by it, or else it becomes just another partisan battleground. So the question arises: How do you create a private body to exert influence on the policymaking process without being part of the government itself? The question of how best to assist policymakers with

malice and to bolster self-defense claim). Stamper has also been interpreted to bar admission of psychiatric testimony that the defendant "lacked the capacity to form the necessary premeditation to commit the offense of capital murder as charged in the indictment." Smith v. Commonwealth, 389 S.E.2d 871, 879-80 (Va. 1990) (citing Stamper, 324 S.E.2d at 688). 
questions that span multiple areas of expertise, like science and law, is complicated. As the sheer volume of scientific knowledge has increased, it seems clear that governmental and quasi-governmental bodies cannot by themselves fully advise and educate policymakers on all of the scientific, legal, and social issues associated with advances in science and technology. In short, there are simply too many issues that would need to be addressed and too few governmental bodies to meet that need.

Instead, the professional communities that have the relevant knowledge and expertise to educate and inform policymakers should combine efforts to serve as a non-governmental, non-partisan advisory body. This ongoing neuroscience and law task force would monitor and assess future scientific developments as they occur and report on these developments to policymakers and the public. In addition to its ongoing deliberations, the task force could serve as "first responder" to emerging events that could affect neuroscience research as well as legal and policy decisions. In this latter capacity, the task force would consider requests from scientists, legal professionals, and policymakers to review and comment on issues of pressing importance and provide information and guidance on these complex matters.

The impact of neuroscience and behavioral genetics on the criminal law offers an opportunity to start such an effort on a small scale, by building on the types of discussions that are included in this volume and in other relevant proceedings. Without such an effort in place, the public policy dialogue will go along in fits and starts-and our policies will be constantly playing "catch up" as the science surges forward. 